\title{
18 Development in Papua after special autonomy
}

\author{
Budy P. Resosudarmo, Julius A. Mollet, \\ Umbu R. Raya and Hans Kaiwai
}

\subsection{INTRODUCTION}

The western part of the New Guinea islands is a unique part of Indonesia. Situated furthest from the nation's capital, Jakarta, it is Indonesia's most sparsely populated and geographically challenging region, and has some of the country's lowest socio-economic indicators. The combination of these difficult geographical and demographic conditions has meant that development in the region has always been challenging (Garnaut and Manning 1972, 1973; Manning and Rumbiak 1989).

Papua formally became part of Indonesia through a long and bitter process that took place between 1963 and 1969. At the time of annexation in 1969, the region was renamed West Irian (Irian Barat) and became a province of Indonesia, with Jayapura as its capital. In 1973, the name was again changed, to Irian Jaya. This controversial history led to the formation of movements among the local elites calling for Papua to become an independent state. Though relatively low level, sporadic and only intermittently violent, these independence movements have consistently challenged the legitimacy of Indonesian rule ever since (McGibbon 2006).

Over the ensuing decades, the Indonesian government attempted to weaken Papuan independence movements and accelerate development by allocating a higher level of funding per capita to Irian Jaya than to the other Indonesian provinces. Critics argued, however, that it was far less than the revenue generated by the region's natural resources. In particular, much of the revenue from the hugely profitable Freeport mine in Mimika district went straight to the central government, fuelling tensions between Jayapura and Jakarta (Resosudarmo et al. 2009a, 2009b). 
The most critical time in the relationship between Jakarta and Jayapura was the period 1998-2001. The resignation of President Soeharto in mid-1998 and East Timor's successful demand for a referendum on independence intensified separatist hopes in Irian Jaya. When Abdurrahman Wahid became president at the end of 1999, he introduced a more accommodative and culturally sensitive approach to the question of ethnic conflict and separatist demands by changing the name of the province to Papua - the name by which parts of the main island were known before contact with the West (Sumule 2003; McGibbon 2004, 2006). To maintain good relations with the provincial elites, the president also endorsed the development of a draft bill on special autonomy for Papua. After a long series of debates, in late 2001 the national parliament finally enacted Law 21/2001 on Special Autonomy for Papua (Resosudarmo et al. 2009a; Widjojo 2010).

The special autonomy legislation gave the provincial government authority over decision making in all sectors except international affairs, defence, monetary and fiscal policy, religion and justice, as well as a far higher share of the revenue originating in Papua than applied to other provinces. It specified that the province would receive 80 per cent of the revenues from its forestry, fishery and mining sectors, and 70 per cent of the revenues from its oil and gas sector until 2026, and 50 per cent thereafter. In addition to the financial transfers from the central government that all provinces receive, until 2021 Papua will receive additional special autonomy funds (dana otsus) amounting to 2 per cent of the total national General Purpose Fund (Dana Alokasi Umum, DAU).

The Indonesian government was slow to implement Law 21/2001. In 2003, before the transition to special autonomy was complete, the central government split Papua into two provinces: Papua with Jayapura as its capital, and West Papua (initially called West Irian Jaya) with Manokwari as its capital. ${ }^{1}$

Despite the efforts of the central government to calm separatist tensions by providing special autonomy and increased funding, there is a widespread perception that development in Papua is a failed process. Critics argue that the benefits of development have been concentrated in resource-rich enclaves and urban areas, bypassing most indigenous Papuans (Widjojo 2010). This chapter investigates Papua's macro-economic and micro-economic performance to establish whether such a perception is warranted. It attempts to understand the factors behind some of the development failures in Papua over the past 10 years, while also drawing attention to the successes.

1 In the rest of the chapter, we refer to the entire region as 'Papua', and to the two provinces separately as 'Papua province' and 'West Papua province'. 
We first review the general development performance of Papua over the past two decades, as represented by trends in economic growth and poverty reduction (section 18.2). In section 18.3, we look more closely at the drivers of growth in each province, especially mining (in the case of Papua province) and liquefied natural gas (LNG) (in the case of West Papua province). Section 18.4 focuses on social and demographic indicators in the two provinces, including poverty, equality, health, rural and urban population growth, and migration. We then discuss interprovincial trends, particularly local government income and expenditure (section 18.5), before providing a few concluding remarks.

\subsection{GENERAL DEVELOPMENT PERFORMANCE}

The two measures adopted in this chapter to assess the general development performance of Papua province and West Papua province since the implementation of special autonomy are the growth of the economy and the progress with poverty alleviation. It is often asserted that the record of the two provinces in these respects has been inferior to that of the rest of the country, so we use the national situation as our benchmark for performance. If Papua province and West Papua province have performed at a similar level to the national average over the past decade or so, it could be argued that they have been doing rather well, in spite of the frequent assertions to the contrary (Widjojo 2010).

Figure 18.1 shows GDP, including and excluding mining, oil and gas, for Papua and for the whole of Indonesia over the two decades from 1993 to 2012, indexed at 100 in 1993 . It shows that the region's growth rates have at least matched those of the national economy. Papua's total GDP increased somewhat faster than the national rate before the enactment of the special autonomy law, and at a similar rate thereafter. Excluding mining, oil and gas, there was a sharp decline in GDP in Papua during the early phase of implementation of the special autonomy law, followed by a recovery from the time of the division into two provinces in 2003.

GDP per capita in Papua grew by approximately 1.9 per cent per annum on average during the period 1993-2012. This was lower than the national rate of 2.9 per cent per annum. Nevertheless, in 2012 the average level of GDP per capita in Papua and in Indonesia as a whole was approximately the same, at Rp 31 million for Papua and Rp 32 million for Indonesia.

Economic growth has been relatively effective in reducing poverty in Papua. Figure 18.2 indicates that the proportion of the population living below the poverty line, as defined by the central statistics agency, Badan Pusat Statistik (BPS), declined in both provinces from about 55 per cent 
Figure 18.1 GDP including and excluding mining, oil and gas, Papua and Indonesia, 1993-2012

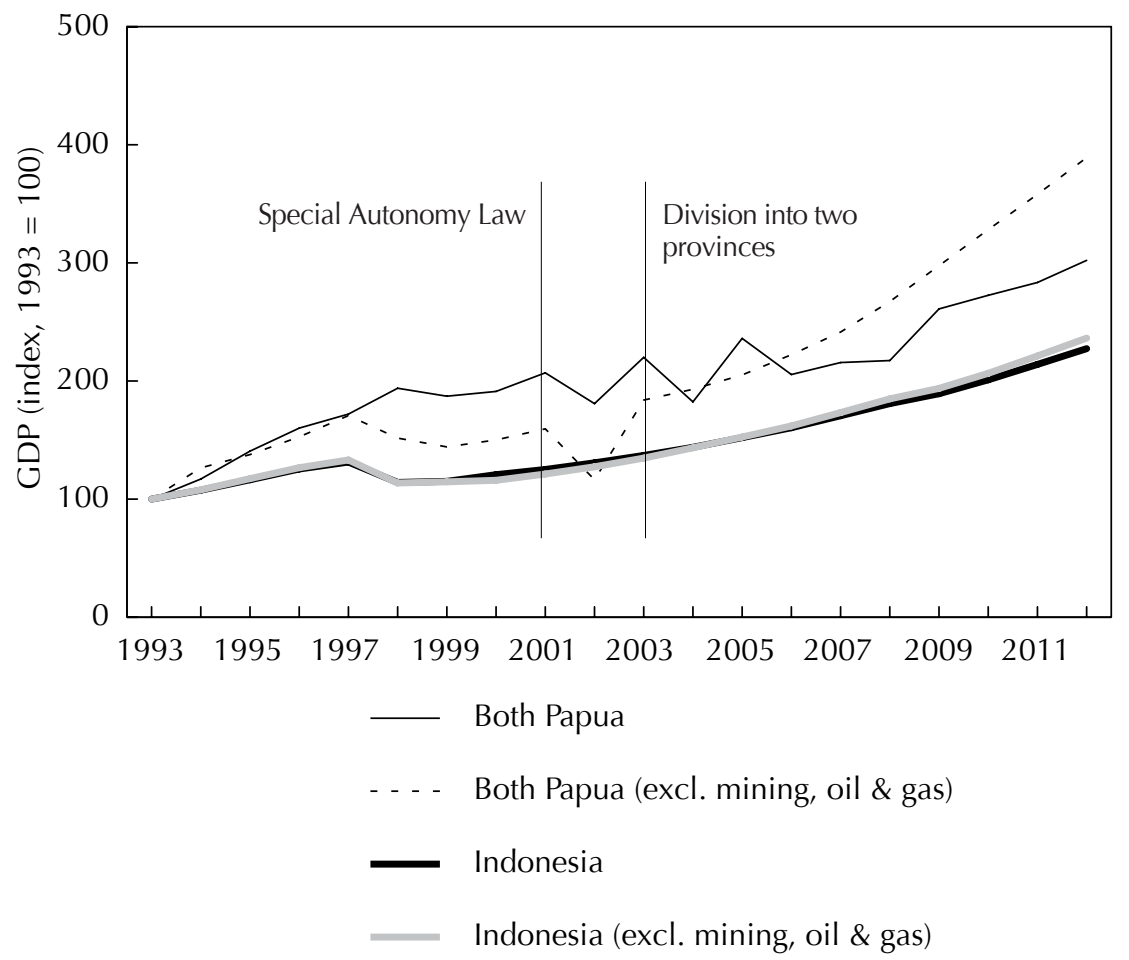

a The figures for 1993-2002 are for the former province of Papua; those for 2003-12 are the combined totals for Papua province and West Papua province.

Source: Provincial GDP data from BPS.

in 1999 to about 30 per cent in 2012. This was still much higher than the national average, of around 12 per cent in 2012, even though poverty has been declining faster than the national average in the two provinces for several years. One could argue that the continuing high levels of poverty in Papua are mainly due to 'initial conditions', that is, to the high proportion of poor people at the start of the special autonomy era (see Ilmma and Wai-Poi, Chapter 5, and Sumarto, Vothknecht and Wijaya, Chapter 12).

Given that the economy has been growing, and poverty declining, at rates at least comparable to the national level since the implementation of special autonomy, it could hardly be argued that development in Papua has been stagnant or has failed. On the contrary, it seems to have been progressing at a relatively good rate. However, we need to look 
Figure 18.2 Share of population below poverty line, Papua province, West Papua province and Indonesia, 1999-2012

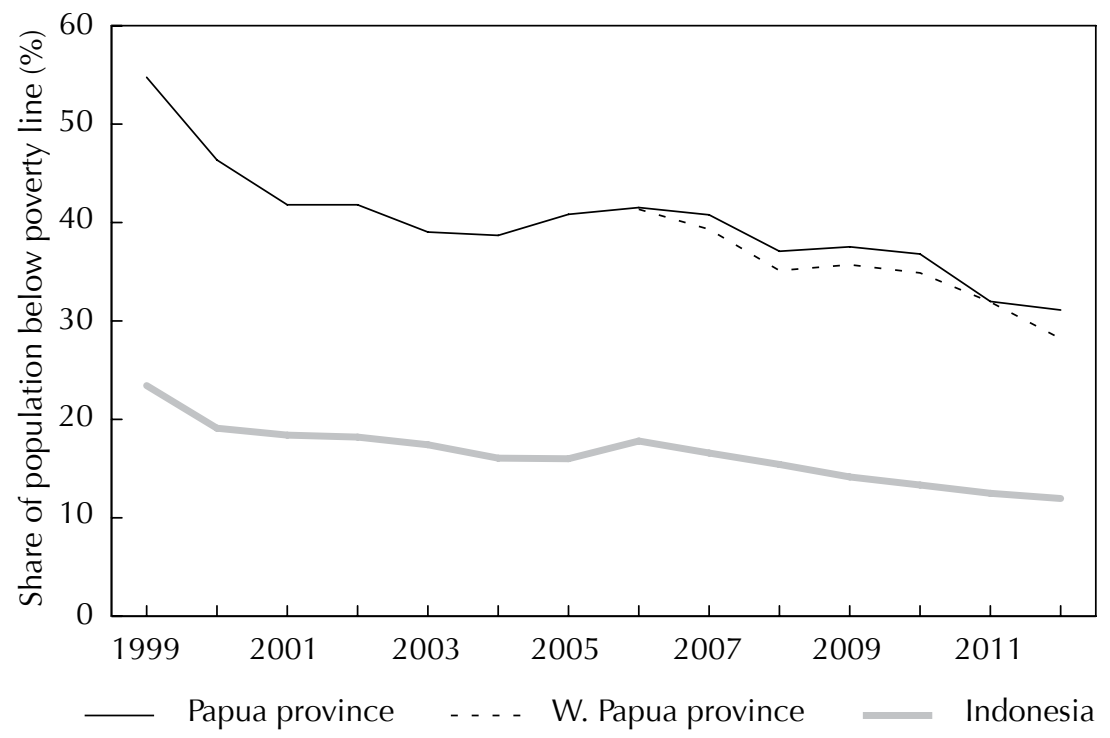

Source: BPS (various years).

more closely at the situation in each province before we can make this assertion with any confidence.

\subsection{ECONOMIC PERFORMANCE}

\section{Economic growth and structural change}

Although the legislation splitting Papua into two provinces was passed in 1999 (Law 45/1999), the process was completed only in 2003, when Abraham Atururi was elected the first governor of the province. Table 18.1 shows economic growth in the original province before it was split into two (1993-2001) and in each province since then (2003-12). On average, West Papua province has recorded yearly growth in GDP of 12.9 per cent since 2003, whereas Papua province has experienced almost no growth. The contrast between the two provinces is starker still when one examines the per capita figures: in 2003-12, GDP per capita grew at an average rate of 9.3 per cent per year in West Papua province, but declined by 5.2 per cent per year in Papua province. Clearly economic development in the region as a whole has been dominated by West Papua province. 
Table 18.1 Components of GDP growth, Papua province and West Papua province, 1993-2012 (\% p.a.)

\begin{tabular}{|c|c|c|c|}
\hline \multirow[t]{2}{*}{ Category/sector } & \multicolumn{2}{|c|}{ Papua province } & \multirow{2}{*}{$\begin{array}{c}\text { West Papua } \\
\text { province } \\
2003-12\end{array}$} \\
\hline & 1993-2001 & 2003-12 & \\
\hline
\end{tabular}

\section{By expenditure category}

\begin{tabular}{lrrr} 
Private consumption & 8.7 & 9.4 & 7.7 \\
Government consumption & 11.6 & 14.5 & 11.6 \\
Fixed capital formation & 9.1 & 12.7 & 6.1 \\
Change in stocks & 13.0 & 35.7 & 18.8 \\
Exports & 12.8 & -9.7 & 15.2 \\
Imports & 12.1 & 5.9 & 7.5 \\
By sector & & & \\
Agriculture & 5.4 & 3.5 & 3.8 \\
Mining \& quarrying & 12.1 & -8.8 & 2.0 \\
Manufacturing & 5.8 & 4.0 & 30.8 \\
Electricity, gas \& water supply & 2.0 & 6.4 & 9.0 \\
Construction & -1.7 & 15.0 & 12.0 \\
Trade, hotels and restaurants & 6.4 & 9.8 & 8.6 \\
Transport \& communications & 7.2 & 13.2 & 11.8 \\
Finance \& business & -2.0 & 19.0 & 14.5 \\
Services & 42.1 & 10.6 & 13.1 \\
Total & & & \\
GDP & 9.5 & 0.2 & 12.9 \\
GDP per capita & 6.8 & -5.2 & 9.3 \\
\hline
\end{tabular}

Source: Provincial GDP data from BPS.

The high economic growth rates in West Papua province are mainly due to the stellar performance of the LNG sector, which grew at an average annual rate of 31 per cent as production from PT BP Indonesia's Tangguh LNG project expanded. Most of this gas has been exported, making exports the main driver of growth on the expenditure side of GDP (Table 18.1). Government consumption is another important source of growth. As a new province and the recipient of generous special autonomy funding, West Papua province has been able to increase government expenditures quite rapidly. Together, the growth of Tangguh LNG and the expansion of government spending have induced growth in other sec- 
tors, such as finance, services, construction, transport and communications, and utilities.

Although Papua province has experienced almost no growth in GDP, the situation is not as serious as one might think. It is true that the mining sector, dominated by PT Freeport Indonesia, has been declining over the last decade or so, leading to a fall in the value of exports. On the other hand, government spending and fixed capital investment have both grown, by well over 10 per cent per year, contributing to growth in sectors such as finance, construction, transport and communications, and trade, hotels and restaurants. With so many sectors still experiencing respectable levels of growth, the impact of the stagnant economy on the welfare of the population will probably be limited. It should also be remembered that mining is typically an enclave activity; its impact on the general public is fairly limited, regardless of whether it is booming or contracting (Weisskoff and Wolf 1977).

Papua has depended heavily on natural resources, especially the mining, oil and gas sectors, since the mid-1970s (Manning and Rumbiak 1989; Resosudarmo et al. 2009a). Although this is still the case, there have been some structural changes in the two provincial economies since the split in 2003 (Table 18.2). The contribution of mining to the economy of Papua province declined from 62 per cent in 2003 to 47 per cent in 2012. The shares of agriculture and manufacturing also fell, but that of utilities remained the same. A few other sectors, notably construction and services, increased their shares during the period. Despite these structural changes, the economy of Papua province continues to be dominated by the mining sector, and in particular by a single company, Freeport Indonesia.

The structure of the West Papuan economy has also changed since the province was established in 2003. The manufacturing sector, dominated by the processing of natural gas from the Tangguh LNG project, sharply increased its share from 16 per cent in 2003 to 54 per cent in 2012, thereby reducing the relative contributions of all other sectors. One could therefore argue that the economy of West Papua province is also dominated by a single company, BP Indonesia, replacing the previous dependence on agriculture and on mining activities in the Salawati Basin.

On the expenditure side, private consumption and international trade have been the most prominent sectors in both provinces (Table 18.2). Import and export performance is determined mainly by the activities of Freeport Indonesia in Papua province, and those of BP Indonesia in West Papua province. In the former province, the growth in both private and government consumption suggests that higher public and private expenditures have compensated for some of the decline in Freeport Indonesia's exports. 
Table 18.2 Structure of the economy, Papua province and West Papua province, 1993-2012 (\%)

\begin{tabular}{lllllll}
\hline Category/sector & \multicolumn{3}{c}{ Papua province } & & \multicolumn{2}{c}{ West Papua province } \\
\cline { 6 - 7 } \cline { 5 - 6 } & & 2003 & 2012 & & 2003 & 2012 \\
\hline
\end{tabular}

\section{By expenditure category}

\begin{tabular}{lrrrrr} 
Private consumption & 53.3 & 45.3 & 62.3 & 66.5 & 35.7 \\
Government consumption & 10.6 & 8.9 & 28.3 & 14.9 & 14.6 \\
Fixed capital formation & 37.5 & 21.2 & 39.8 & 42.7 & 23.5 \\
Change in stocks & 3.6 & 3.7 & -3.6 & 3.4 & 12.1 \\
Exports & 42.3 & 71.8 & 36.7 & 50.4 & 47.5 \\
Imports & 47.3 & 50.9 & 63.6 & 78.0 & 33.3 \\
By sector & & & & & \\
Agriculture & 22.3 & 15.4 & 12.6 & 31.9 & 12.2 \\
Mining \& quarrying & 50.9 & 61.5 & 46.5 & 18.4 & 6.5 \\
Manufacturing & 4.8 & 2.3 & 1.9 & 15.9 & 54.0 \\
Electricity, gas \& water supply & 0.3 & 0.2 & 0.2 & 0.4 & 0.3 \\
Construction & 9.3 & 4.1 & 13.0 & 7.0 & 7.3 \\
Trade, hotels \& restaurants & 5.7 & 5.1 & 6.8 & 10.0 & 6.6 \\
Transport \& communications & 3.6 & 3.9 & 6.5 & 6.3 & 4.7 \\
Finance \& business & 2.4 & 1.0 & 3.0 & 1.5 & 1.9 \\
Services & 0.7 & 6.5 & 9.5 & 8.5 & 6.6 \\
\hline
\end{tabular}

Source: Provincial GDP data from BPS.

Observing the dynamics of economic growth and structural change in the two provinces, one can conclude that each is heavily reliant on a single industry - indeed, a single company - extracting natural resources. When the exports of either of those companies decline, due to a fall in world prices or to a reduction in output, inevitably the economy of the province concerned will contract or stagnate. To reduce the high dependency in both provinces on extractive industries, policies should be developed to encourage the development of other sectors. One option would be to expand the agricultural and agricultural processing sectors, because the contribution of agriculture to both provincial economies is second only to mining, and because these sectors could potentially absorb large numbers of workers. However, this does not mean that the development of other sectors, such as construction, and trade, hotels and restaurants, is not important. 
Figure 18.3 Annual revenue of Freeport-Indonesia, 2005-12

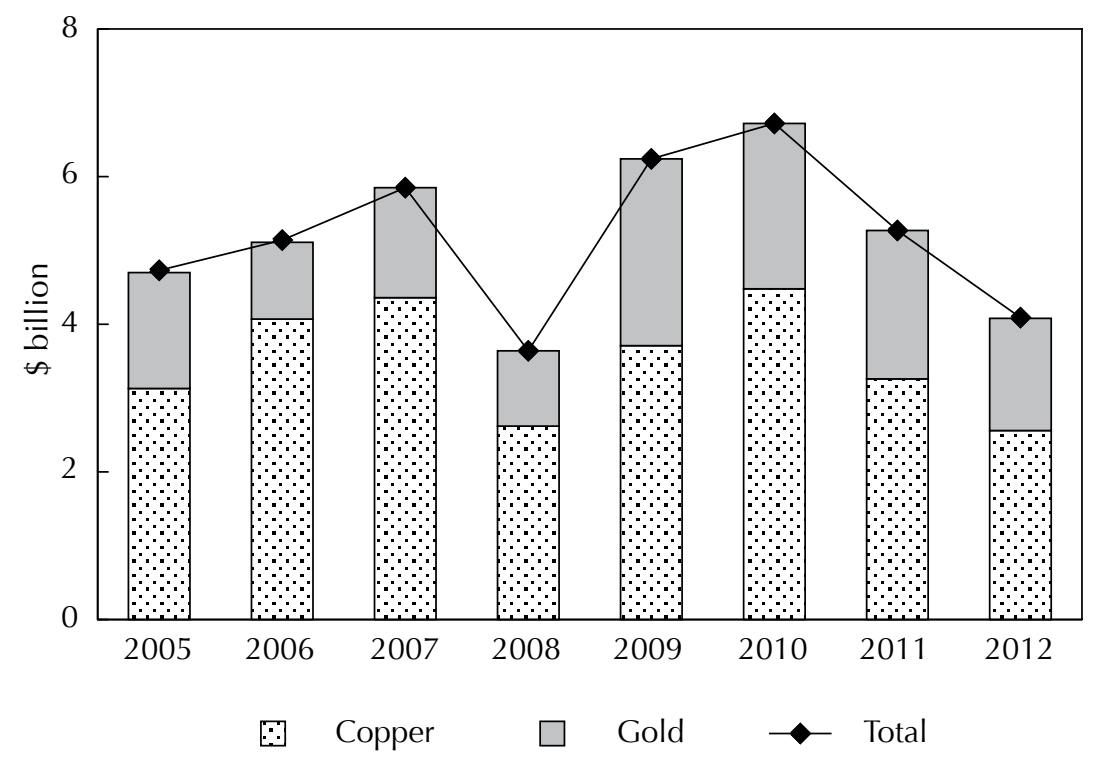

Source: Annual reports of Freeport-McMoRan Copper \& Gold, Inc.

\section{Mining and gas}

PT Freeport Indonesia has long been the most significant mining operation in Papua province. It is part of Freeport-McMoRan Copper \& Gold Inc., which has its headquarters in Phoenix, Arizona. The company initially mined copper and gold in the remote and rugged Ertsberg area, but since 1988 has concentrated on the Grasberg area, which is about 70 kilometres from the city of Timika (Ballard and Banks 2009). Since commencing operations in 1967, Freeport has grown into a hugely profitable company, mostly due to its exceptionally low production costs and its correspondingly high profit margins. In 2010 its annual revenue reached $\$ 6.7$ billion, and in 2011 it paid about $\$ 1.9$ billion to the Indonesian government in tax. The company directly employed over 24,000 staff in 2011, making Freeport one of the largest private sector employers in the whole of Indonesia (Freeport-McMoRan Copper \& Gold Inc. 2013).

Freeport has dominated the economy of Papua for many years. For much of that time it constituted 50 per cent or more of the provincial economy and contributed 90 per cent of Papua's total exports. Since 2005, however, Freeport Indonesia's revenues have been fairly stagnant, or declining (Figure 18.3). The main reason for this is the relatively stable 
world copper prices during the period 2005-10, followed by a decline since then, without any corresponding significant increase in production. The fall in the value of production since 2005 is responsible for the decline observed earlier in the value of Papua province's exports.

The size of the mining industry is such that there is little incentive for the provincial government to make serious efforts to develop other sectors. Meanwhile, the benefits of this industry for local communities are debatable: the company directly employs only 4,000 or so indigenous Papuans, and the living conditions of the tribes living in the Grasberg area are still very basic. Critics also argue that the higher share of mining revenue flowing to the provincial government since the implementation of special autonomy has mainly benefited the residents of Jayapura, where most of the money has been spent. That is, the combination of a limited number of indigenous Papuans absorbed by this industry, the urban concentration of government spending and the failure to develop other sectors has greatly limited the benefits of the mining industry for Papuans in general, and for rural communities in particular.

West Papua province hosts two main types of mining activities. The longer-established one is the oil and gas mining in the seas off Sorong district and Salawati Island, which began in 1964 (Anggraeni 2007). This was important in the development of Sorong city and the surrounding areas, although its contribution paled beside that of Freeport. In 2001, for example, before Papua was divided into two provinces, oil and gas mining in the Salawati and Sorong areas contributed approximately 4.5 per cent of Papua's GDP and 3 per cent of its exports - far less than Freeport.

The more recent and much more significant activity is LNG extraction by BP Indonesia in the Bintuni Bay area. The company launched its Tangguh LNG project in 2005, with production commencing in 2009. Since then, this single company has dominated the economy of West Papua province. By 2012, the Tangguh LNG project accounted for about 42 per cent of the province's GDP and employed around 3,400 people, 54 per cent of them Papuan. The company is planning a major expansion of operations, so it is expected to remain the main driver of the provincial economy for some years to come (TIAP 2012).

Although BP Indonesia seems to have been able to recruit a higher proportion of Papuan employees than Freeport, the benefits of its extraction activities again appear to be concentrated in urban areas. As in Papua province, the large revenues flowing from this single sector can be expected to detract from efforts to develop other economic sectors. The impact of gas extraction on rural development could be limited unless there are concerted efforts to spread the benefits to other sectors, and to rural areas. 
Figure 18.4 Share of population below poverty line by urban/rural area, Papua province and West Papua province, 2006-12

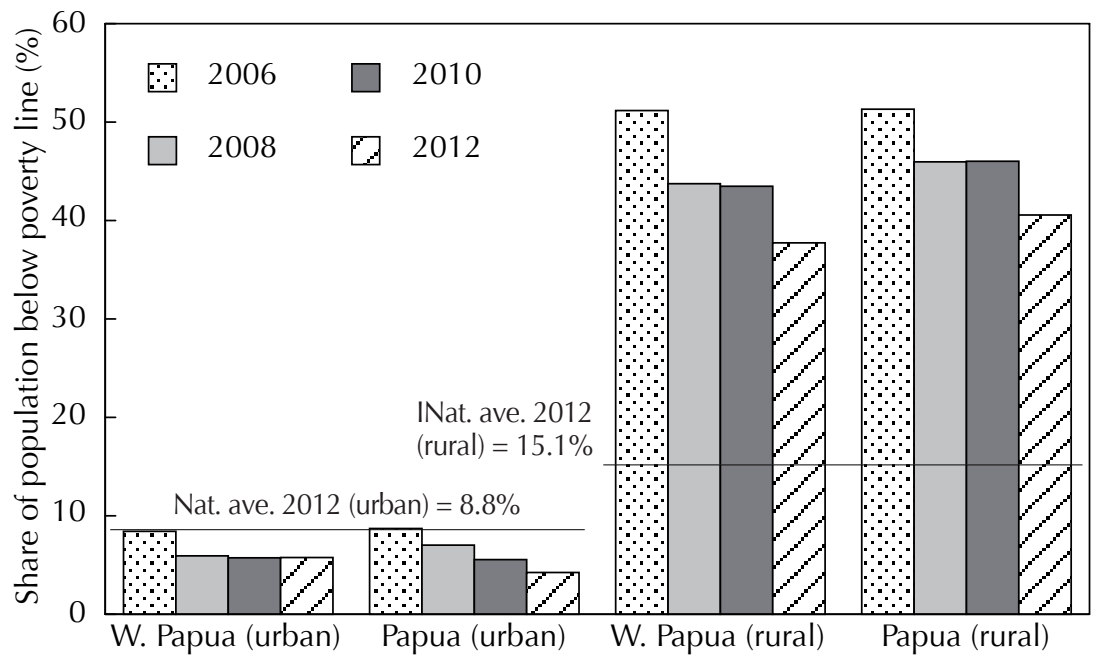

Source: BPS (various years).

\subsection{SOCIAL AND DEMOGRAPHIC INDICATORS}

\section{Poverty}

Although poverty in aggregate has declined in both Papuan provinces (see section 18.2), there may still be important differences in poverty levels within each region. In this section we investigate levels of poverty in rural and urban areas. This is a very relevant distinction in the case of Papua, where the rural and urban economies are very different. In particular, government and services are very important in urban areas, whereas agriculture dominates the rural economy. The composition of the urban and rural populations is also different, with relatively few migrants from other parts of Indonesia living in rural areas, and relatively few Papuans living in urban areas.

Figure 18.4 shows the proportion of the rural and urban populations living below the poverty line, as defined by BPS, in Papua and West Papua provinces. It can be seen that the level of both rural and urban poverty declined continuously in the two provinces between 2006 and 2012. Poverty fell faster in rural than in urban areas, but with no prospect of closing the gap. In 2012, urban poverty in both provinces was lower than the average for Indonesia's urban areas of approximately 9 per cent. This was far from the case for rural poverty, however, which was much 
higher than the national average for rural areas of around 15 per cent. Around 41 per cent of rural dwellers in Papua province, and 38 per cent in West Papua province, were classified as poor in 2012. In short, poverty in both provinces is very much a rural phenomenon.

Programs to develop rural areas and improve the productivity of the rural poor have arguably contributed to the observed decline in rural poverty in Papua. Yet, the fact that rural poverty remains very high does raise questions about the effectiveness of such programs. One of the more recent initiatives is the Strategic Village Development Plan (Rencana Strategis Pembangunan Kampung, Respek) introduced in 2007. It aims to develop local economies by distributing Rp 100 million (about $\$ 10,000)$ to each village in Papua province and West Papua province, with the funds to be used to improve nutrition, basic education, primary health care, infrastructure and livelihoods. To improve the effectiveness of this program, in 2008 Respek was merged with the National Community Empowerment Program (Program Nasional Pemberdayaan Masyarakat, PNPM) (see Chapter 10 by McCarthy et al.). In 2013, it was renamed the Strategic Village Economic and Institutional Development Program (Program Strategis Pembangunan Ekonomi dan Kelembagaan Kampung, Prospek), indicating an additional emphasis on village institutional development.

The success of this program is debatable, with both good and bad reports. In some villages, it has reportedly induced the development of some small-scale, post-harvest agricultural industries. In others, however, it appears to have discouraged indigenous farmers from growing staple foods and vegetables, thereby possibly reducing the availability of some foods in those villages. Apart from any conclusions that may be drawn about the program, combating poverty in rural areas is still the main development challenge facing the provinces of Papua and West Papua.

\section{Income equality}

The Gini coefficient is a measure of income distribution among a population, with a rise in the ratio representing an increase in inequality. The Gini increased from 0.37 in Papua province and 0.31 in West Papua province in 2007 to about 0.42 in both provinces in 2012. This was not very different from the ratios for Indonesia as a whole, of 0.33 in 2007 and 0.41 in 2012. The rise in income inequality in the two provinces, and in Indonesia, was not because the incomes of the poor were not growing - they have in fact grown - but rather because the incomes of the rich have been growing much faster than those of the poor.

Figure 18.5 shows average annual growth in household expenditure per capita in 2008-12, in real terms, from the poorest percentile of the 
Figure 18.5 Distribution of average annual growth in household expenditure per capita, Papua and Indonesia, 2008-12

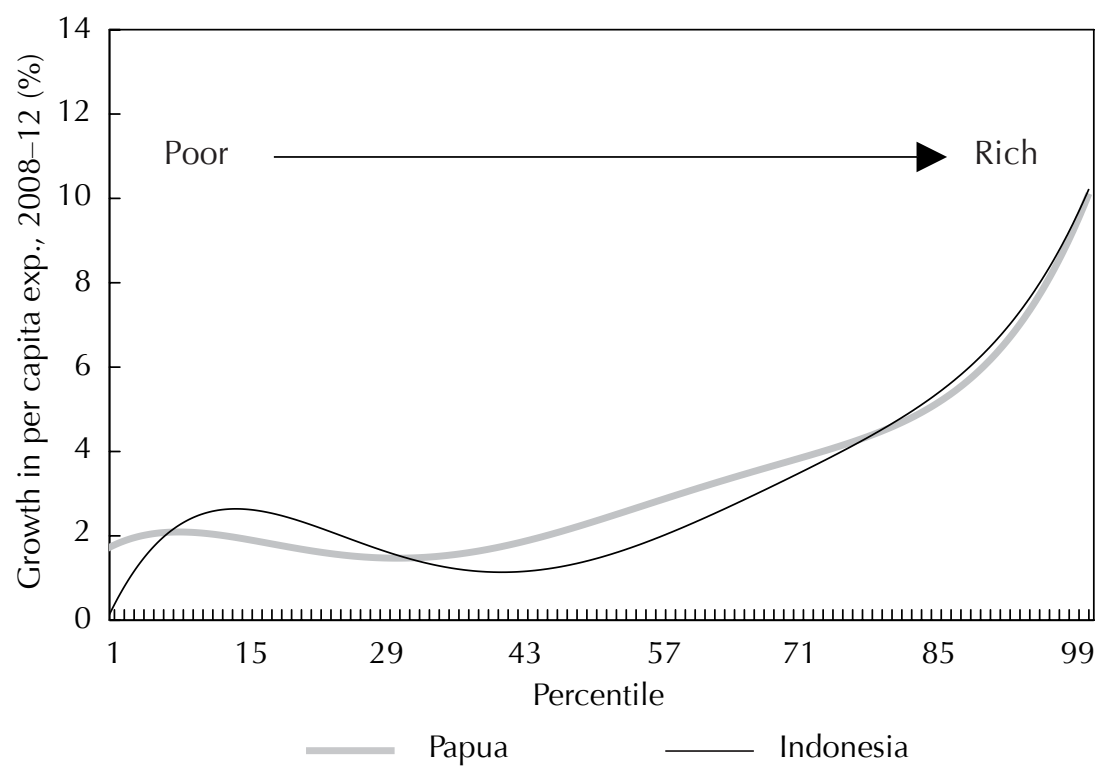

Source: Authors' calculation based on 2008 and 2012 Susenas.

population (on the left) through to the richest percentile (on the right), for both Papua and Indonesia. Expenditure per capita is used as a proxy of income, since it is typically difficult to obtain accurate information on income in developing countries such as Indonesia.

It can be seen that, on average, the income of the poorest 1 per cent of the population grew by less than 0.5 per cent per year in Papua (and less than 2 per cent in Indonesia as a whole), rising to roughly 10 per cent annually for the richest 1 per cent of the population, both in Papua and nationally. This suggests that the very rich have benefited more from development than other segments of the population. Since most rich people in Papua live in urban areas, and most of the poor in rural areas, it follows that urban dwellers have been the main beneficiaries of development. In Papua, a Gini coefficient of 0.42 in 2012 implies average household expenditure per capita for the poorest percentile of the population of about $\operatorname{Rp} 120,000$ per month, rising to around $\operatorname{Rp} 5.5$ million per month for the richest percentile. ${ }^{2}$ That is, regardless of whether one

2 Based on data from the first quarter of the 2012 National Socio-Economic Survey (Survei Sosio-Ekonomi Nasional, Susenas). 
considers the distribution of income growth or absolute levels of income, there is clearly a case for redistributing the benefits of development from the richer, mainly urban communities, to poorer rural populations. Among the solutions would be a more progressive tax system and social programs targeting the poor.

\section{Health}

Health outcomes are another commonly used welfare indicator. Here, we focus on the incidence of certain diseases. It is important to note, however, that in Indonesia the incidence of common diseases is generally based on reported cases in hospitals and health centres. These numbers may not be reliable, since many people who are in need of treatment do not attend health clinics or hospitals (Sedyaningsih and Gunawan 2009). In regions with poor services, low socio-economic indicators and difficult terrain, such as the provinces of Papua and West Papua, the numbers are almost certainly underestimates.

Figure 18.6 shows the incidence of three of the most serious diseases in Papua province and West Papua province - tuberculosis, malaria and AIDS - in comparison with other island groups. In 2010, the two provinces recorded the highest incidence of tuberculosis in the country, of 227 cases per 100,000 people in Papua province, and 195 in West Papua province. Maluku recorded the next highest incidence, with 170 cases per 100,000 people. The incidence of malaria is also higher in the two Papuan provinces than in any other island group - at least three times higher in 2010 than any other region except Nusa Tenggara.

Tuberculosis and malaria are among the biggest killers in Papua. Rates are persistently high in coastal areas, including urban coastal areas (Sedyaningsih and Gunawan 2009). This suggests that the efforts of the two provincial governments to target the diseases through various health programs have so far not been successful, even in urban areas where poverty is not widespread.

AIDS has also become a serious health problem, in Papua province in particular. In 2011, the cumulative number of recorded cases was approximately 180 per 100,000 people. Not only is this higher than in other regions in Indonesia, but it is also a significant increase on the 20 cases per 100,000 people recorded in 2002. The disease has now spread beyond sex workers and drug users into the general community, and beyond the mining towns into both urban and rural areas. The causes of the disproportionately high number of cases in Papua province can be traced to patterns of migration, poor literacy, inadequate education campaigns and a shortage of prevention and treatment programs (Freund 2007; National AIDS Commission 2009; Sedyaningsih and Gunawan 
Figure 18.6 Incidence of tuberculosis, malaria and AIDS by major island group, 2010-11

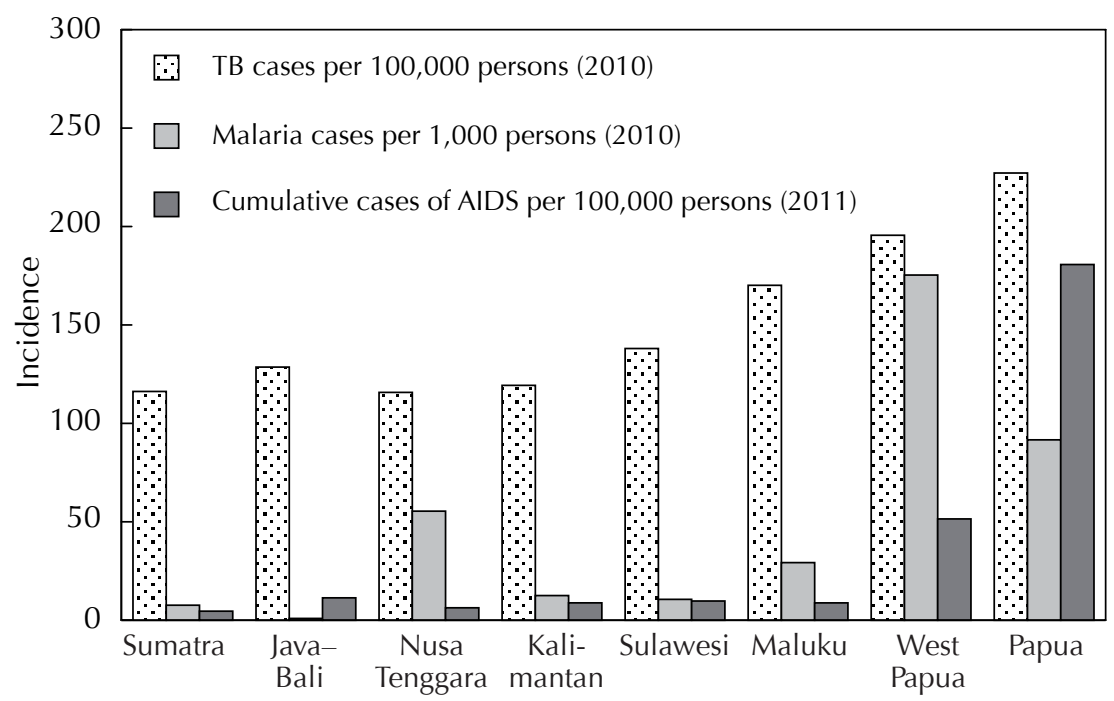

Source: Ministry of Health, Database Kesehatan, http://www.bankdata.depkes.go.id.

2009). More worrying still is the fact that the rates presented in Figure 18.6 are most likely substantial underestimates. Especially if they are living in rural areas, many Papuans are simply not aware that they may be infected and so do not show up at a hospital or health centre.

\section{Population change and human development}

According to the 2010 population census, the combined population of the two Papuan provinces is 3.6 million (Table 18.3). The population increased by 4.9 per cent annually between 2000 and 2010 . This was three times the national rate, and higher than during the previous two decades, when the population grew by just over 3 per cent annually. Nevertheless, population density remains low, at around eight or nine people per square kilometre. This is half the density in other resource-rich provinces such as East Kalimantan (17 persons per square kilometre), and certainly much lower than in Sumatra and Java.

An influx of non-Papua-born citizens over the past decade or so has contributed significantly to Papua's high and rising population growth rates. During 2000-10, the annual growth rate of the non-Papua-born population was approximately 4.8 per cent for recent migrants and 6.7 per cent for lifetime migrants (Table 18.3). These migrants have tended 
Table 18.3 Population dynamics in Papua, 1980-2010

\begin{tabular}{|c|c|c|c|c|c|}
\hline & \multicolumn{3}{|c|}{ Growth rate (\% p.a.) } & \multirow{2}{*}{$\begin{array}{c}\text { Share of } \\
\text { total, } 2010 \\
(\%)\end{array}$} & \multirow{2}{*}{$\begin{array}{l}\text { Population } \\
\text { (thousand) }\end{array}$} \\
\hline & 1980-90 & 1990-2000 & 2000-10 & & \\
\hline Total & 3.5 & 3.0 & 4.9 & 100.0 & 3,594 \\
\hline Lifetime migrant & 10.6 & 3.1 & 6.7 & 19.1 & 686 \\
\hline Recent migrant & 8.2 & 0.2 & 4.8 & 3.4 & 120 \\
\hline Non-migrant & 2.3 & 3.1 & 4.5 & 77.6 & 2,787 \\
\hline Urban & 5.1 & 5.5 & 4.6 & 26.1 & 937 \\
\hline Rural & 3.5 & 2.3 & 5.0 & 73.9 & 2,657 \\
\hline
\end{tabular}

a Lifetime migrants are those who currently live in a province that is different from the province of birth. Recent migrants are migrants aged five years or over who reside in a different province from their province of residence five years previously. For purposes of comparison, people who were born in West Papua but now live in Papua province, and vice versa, are categorized as non-migrants.

Source: Authors' calaculation based on 1980, 1990, 2000 and 2010 population censuses.

to settle in urban areas, where they probably account for at least half the population (Resosudarmo et al. 2009a).

One main cause of the high growth in the migrant population over the past few years has been the sudden increase in demand for skilled labour. For example, the activities of BP Indonesia in the Bintuni Bay area since 2009 have led to a sharp increase in demand for managerial and mining skills. Because of the limited availability of such skills among native Papuans, the company has had to recruit from other parts of the country, increasing the in-migration rate. BP Indonesia has set a quota for its Tangguh LNG project of 85 per cent of jobs to be filled by indigenous Papuans by 2029, but in 2012, 46 per cent of its 3,400 workers were still non-Papuan (TIAP 2012; BP 2013). Given the slow response from the Papuan side to the need for skilled labour, the likely expansion of the Tangguh LNG project and the prospect of new oil and gas tenements being developed in the future, ${ }^{3}$ the demand for skilled labour from outside Papua is unlikely to abate soon.

As well as being a recipient of skilled migrants, Papua has long been viewed as a suitable site for the central government's transmigration

3 In December 2009, the Indonesian government offered a new tender for 24 oil and gas blocks, including one in West Berau (near BP Indonesia's current site of operation) and five in Cenderawasih Bay; see 'Indonesia opens 24 new oil and gas blocks for tender and direct offer', energy-pedia news, 1 December 2009. 
program because of its low population density. The Ministry of Transmigration says it has identified 5.87 million hectares of land in Papua suitable for transmigration settlements. It aims to move around 10,000 people from West Java and East Java annually to other places in Indonesia, including Papua, where some previous sites have developed into thriving horticultural supply centres. In 2010, the governors of West Java and West Papua signed an agreement that would see 700 West Javanese farming households migrate annually to West Papua. ${ }^{4}$

Migrants entering Papua under government transmigration schemes and to meet the demand for skilled workers do not provide the entire explanation for the increase in the overall number of migrants in Papua over the last 10 years or so. Of course, in addition to skilled workers and transmigrants, many people come to Papua to work in service sectors such as transport and trade, hotels and restaurants, or to set up small businesses. Data from the 2010 population census suggest that, like skilled migrants and transmigrants, most of them have settled in urban areas.

Although the Papua-born population grew more slowly than the migrant population - by 4.5 per cent in 2000-10, compared with 6.7 per cent for lifetime migrants and 4.8 per cent for recent migrants (Table 18.3 ) - non-migrants still form the majority of the population (78 per cent in 2010). The rural population has been growing faster than the urban population: by 5.0 per cent per annum over the period 2000-10, compared with 4.6 per cent for the urban population. This could reflect improvements in health care in rural areas, but it is still a surprisingly high growth rate for Papua's slower-growing rural economy.

Overall, migrants are better educated than the average Papua-born citizen (Figure 18.7). The educational attainment of recent migrants is similar to that of lifetime migrants, with the majority having at least a junior secondary education. Most non-migrants, on the other hand, have gone no further than primary or junior secondary school. Among the non-migrants, West Papuans are better educated than Papuans: more than 50 per cent of Papuans, but only 20 per cent of West Papuans, have just a primary education.

Given the persistent shortage of specific skills in the mining and oil and gas sectors, and the expectation that more projects will come on stream in the future, the need for well-educated workers will only grow in the short to medium terms. For Papua-born citizens to play a bigger part in fulfilling this demand, local governments will need to invest more in education, especially tertiary education. This should be accompanied by strategies to ensure that knowledge and skills are transferred

4 '5 juta ha lahan transmigrasi di Papua Barat' [5 million hectares of transmigration areas in West Papua], Viva News, 10 February 2010. 
Figure 18.7 Educational attainment among migrants and non-migrants, Papua province and West Papua province, 2010

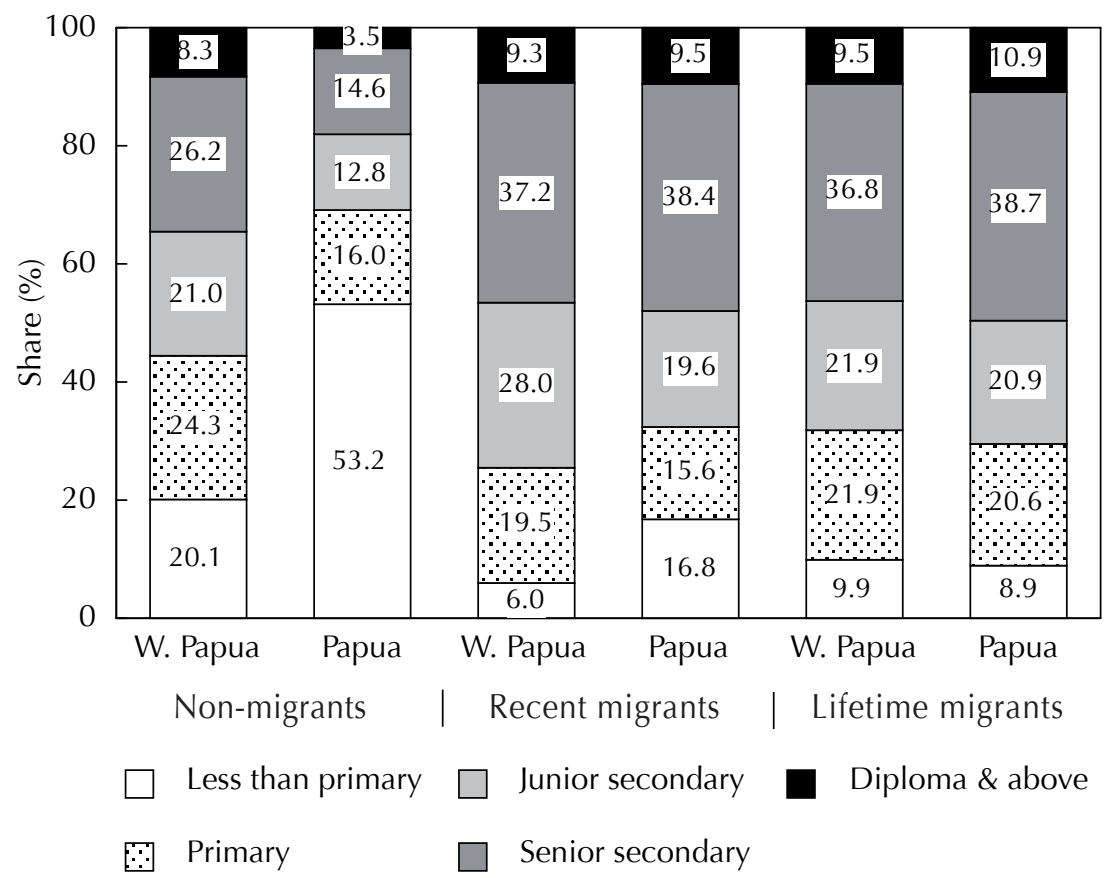

a Lifetime migrants are those who currently live in a province that is different from the province of birth. Recent migrants are migrants aged five years or over who reside in a different province from their province of residence five years previously. For purposes of comparison, people who were born in West Papua but now live in Papua province, and vice versa, are categorized as non-migrants.

Source: Authors' calculation based on 2010 population census.

from migrants to non-migrants, in order to improve the social returns to education.

Because most migrants are better educated than non-migrants, they tend to have higher incomes than the average Papuan. They and the richer Papuans generally live in urban areas. It is therefore not surprising that the urban population has so far benefited disproportionately from development in the two provinces.

\subsection{REGIONAL DEVELOPMENT}

In this section, we try to identify the areas within the provinces of Papua and West Papua that have benefited most from development since the 
Table 18.4 GDP and private expenditure by district, Papua province and West Papua province, 2003-11

\begin{tabular}{lrrrr}
\hline $\begin{array}{l}\text { District/group } \\
\text { of districts }\end{array}$ & $\begin{array}{r}\text { Growth } \\
\text { of GDP, } \\
2003-11 \\
\text { (\% p.a.) }\end{array}$ & $\begin{array}{c}\text { Growth of } \\
\text { GDP per } \\
\text { capita, } \\
2003-11 \\
\text { (\% p.a.) }\end{array}$ & $\begin{array}{c}\text { GDP } \\
\text { per capita, } \\
2011 \\
\text { (Rp thousand) }\end{array}$ & $\begin{array}{c}\begin{array}{c}\text { Private } \\
\text { expenditure } \\
\text { per capita, } \\
2011 \\
\text { (Rp thousand) }\end{array} \\
\text { West Papua province }\end{array}$ \\
$\begin{array}{l}\text { Greater Sorong area } \\
\text { a }\end{array}$ & 4.6 & 2.0 & 36,209 & 8,450 \\
Manokwari district & 8.7 & 5.3 & 18,049 & 8,128 \\
Teluk Bintuni district & 39.5 & 33.6 & 298,731 & 11,555 \\
Other districts & 8.7 & 5.2 & 22,880 & 6,634 \\
Papua province & & & & \\
Greater Jayapura area ${ }^{\mathrm{a}}$ & 12.0 & 8.3 & 31,050 & 9,960 \\
Mimika district & -7.1 & -12.0 & 239,083 & 10,354 \\
Merauke district & 6.9 & 4.8 & 21,234 & 7,135 \\
Other districts & 5.8 & -4.5 & 7,035 & 5,315 \\
\hline
\end{tabular}

a The greater Sorong area consists of Sorong district and Sorong municipality; the greater Jayapura area consists of Jayapura district and Jayapura municipality.

Source: Authors' calculation based on regional GDP data from BPS.

split in 2003. Table 18.4 shows regional GDP in the greater Sorong area (consisting of Sorong district and Sorong city), Manokwari district, Teluk Bintuni district and 'other' districts (within West Papua province); and in the greater Jayapura area (consisting of Jayapura district and Jayapura city), Mimika district, Merauke district and 'other' districts (within Papua province).

In West Papua province, the greater Sorong area and Teluk Bintuni district are both resource-based, development-driven regions. Oil and gas activities have driven development in Sorong, and the activities of Tangguh LNG in Teluk Bintuni. Growth in Manokwari district, on the other hand, has been heavily reliant on government spending. The capital cities of the districts of Sorong and Manokwari - Sorong city and Manokwari city - are relatively large municipalities that act as growth centres for the surrounding regions.

From Table 18.4 it can be seen that Teluk Bintuni's GDP has grown so rapidly that its income per capita was around 10 times that of the other regions in 2011. The greater Sorong area registered the slowest growth of both GDP and GDP per capita in 2003-11, due to the slower rate of 
expansion of oil and gas projects. Income per capita in Manokwari and the 'other' districts grew at about the same rate (just over 5 per cent) and their levels of per capita income in 2011 were broadly similar. Hence, if one excludes Teluk Bintuni, it appears that development has been relatively equally distributed across the province.

In Papua province, growth in the greater Jayapura area, including the capital city of Jayapura, has been driven by government spending, and that of Mimika by its resources. In Merauke, the relatively large capital city of Merauke once again acts as a growth centre for the surrounding district.

Both GDP and GDP per capita in Mimika district have contracted over the last few years as Freeport Indonesia's revenue and exports have slowed. Nevertheless, it remains a relatively rich region in terms of income per capita. The region with the fastest growth has been the greater Jayapura area, where GDP grew by 12 per cent per annum in 2003-11, and GDP per capita by 8 per cent, making it the second-richest region in Papua province after Mimika. GDP in Merauke and the 'other' districts grew at around half the rate of the greater Jayapura area. GDP per capita in the 'other' districts actually contracted between 2003 and 2011, with the result that they recorded the lowest income per capita in 2011. One can conclude that the greater Jayapura area has so far captured most of the benefits of development in Papua province.

\section{Government expenditure}

Government expenditure, by both the central government and local governments, is an important sector in the two Papuan provinces. As revealed in the regional accounts, it has been growing quite quickly by over 10 per cent annually during the past decade or so. Government expenditure makes an important contribution to the economies of the two provinces, and creates significant multiplier effects in other sectors. For example, government spending on roads and transport not only directly expands the construction and transport sectors, but also induces expansion in other sectors such as trade, agriculture and manufacturing. This section discusses the size and types of local government expenditure, for both the provincial and district governments. It does not examine central government expenditures in the two Papuan provinces, which are more difficult to dissect.

Local governments in Papua derive most of their income from the DAU, from the special autonomy funds (dana otsus) available only to Papua and Aceh, and from their own natural resources (the latter through revenue sharing with the central government; see section 18.1 above). In 2011, these three sources of income accounted for about 46 per cent, 25 
Figure 18.8 Local government expenditure per capita by major island group, 2007 and 2011

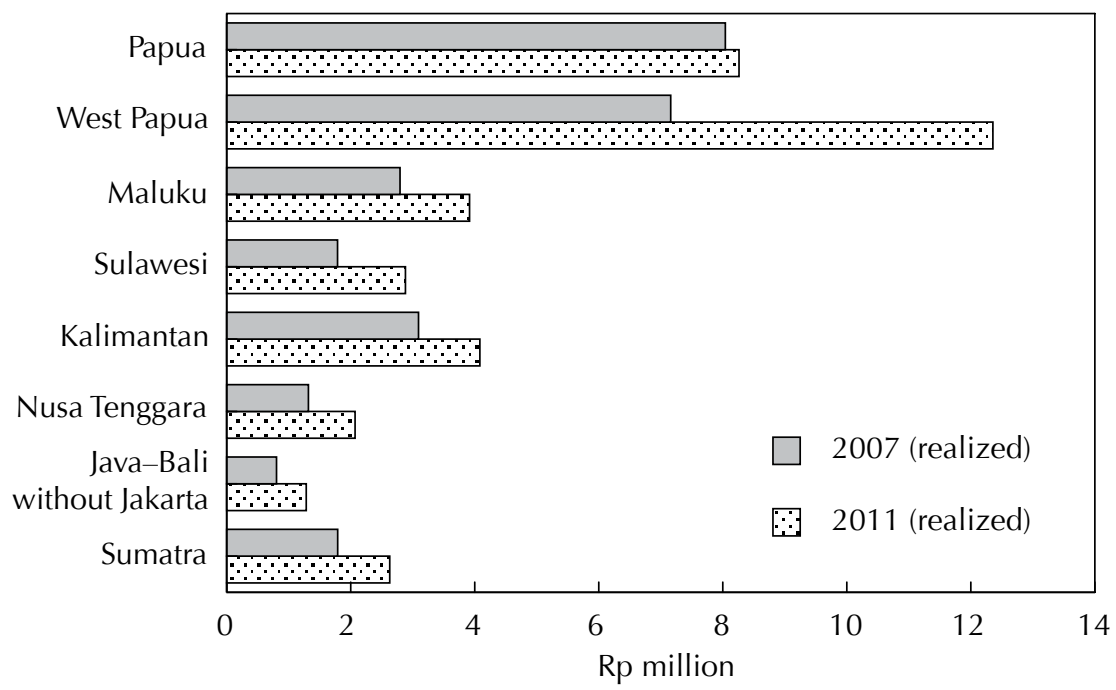

Source: Authors' calculation based on data from Directorate General for Fiscal Balance (2013).

per cent and 9 per cent respectively of total income in Papua province, and 34 per cent, 29 per cent and 21 per cent in West Papua province. By comparison, the shares of total income for all Indonesian provinces were 44 per cent (DAU) and 17 per cent (revenue sharing). Transfers from the Special Purpose Fund (Dana Alokasi Khusus, DAK) were more important for Papua province (7 per cent of total local government income) than for West Papua province (5 per cent). Own-source revenue (pendapatan asli daerah, PAD) has been relatively unimportant in both provinces, constituting just 3 per cent of total local government income in both provinces in 2011. Both provinces have put most of their income to use: Papua province was able to spend approximately 88 per cent of its income in 2011, and West Papua province 93 per cent.

Although small compared with those of middle-income and developed countries, ${ }^{5}$ the per capita expenditures of the Papua and West Papua provincial governments are relatively large compared with those of other Indonesian provinces and some other developing countries. Figure 18.8 shows that, in both 2007 and 2011, realized per capita government expenditures in the two provinces were at least twice those in the other major island groups. In 2011, government expenditure was just

5 See http://www.principalglobalindicators.org/default.aspx. 
Table 18.5 Structure of government expenditures in Papua province and West Papua province, 2010 (\%)

\begin{tabular}{lrrr}
\hline Category & $\begin{array}{c}\text { West Papua } \\
\text { province }\end{array}$ & $\begin{array}{c}\text { Papua } \\
\text { province }\end{array}$ & $\begin{array}{c}\text { National } \\
\text { average }\end{array}$ \\
\hline General services & 53.5 & 49.1 & 32.5 \\
Order \& security & 1.2 & 0.7 & 0.9 \\
Economic & 9.5 & 10.6 & 8.9 \\
Environment & 0.5 & 0.5 & 1.7 \\
Housing \& public facilities & 17.4 & 16.1 & 14.5 \\
Health & 5.0 & 8.4 & 9.8 \\
Tourism \& culture & 0.6 & 0.6 & 0.6 \\
Education & 10.1 & 12.5 & 29.7 \\
Social protection & 2.2 & 1.6 & 1.3 \\
\hline
\end{tabular}

Source: Authors' calculation based on data from Directorate General for Fiscal Balance (2013).

over Rp 8 million per capita in Papua province, and more than Rp 12 million in West Papua province.

The main problem in Papua is not so much the amount of government expenditures but how the money is allocated. The largest expenditure item in the provincial budgets is general administration (employees' salaries, building maintenance and other items related to local government facilities), most of which is spent in urban areas (Table 18.5). In 2010, the national average for local government expenditure on general administration as a share of total expenditure was a rather high 33 per cent (see Lewis, Chapter 6), but in Papua province and West Papua province the shares were far higher, at 54 per cent and 49 per cent respectively. The consequence of this high spending on general administration is that not much is left over to fund other priorities. For example, although required by Law 20/2003 on the National Education System to spend at least 20 per cent of their budgets on education (Suryadarma and Jones 2013), in 2010 Papua province and West Papua province spent only 10 per cent and 13 per cent respectively on this sector. Spending on much needed social protection measures was lower still, at around 2 per cent of total expenditures in both provinces.

Clearly the structure of local government expenditures in both provinces needs to change so that far less is spent on general administration and far more on the economic, health, tourism, education and social protection sectors. 
Figure 18.9 Electricity consumption per capita by major island group ( $k W h$ per capita)

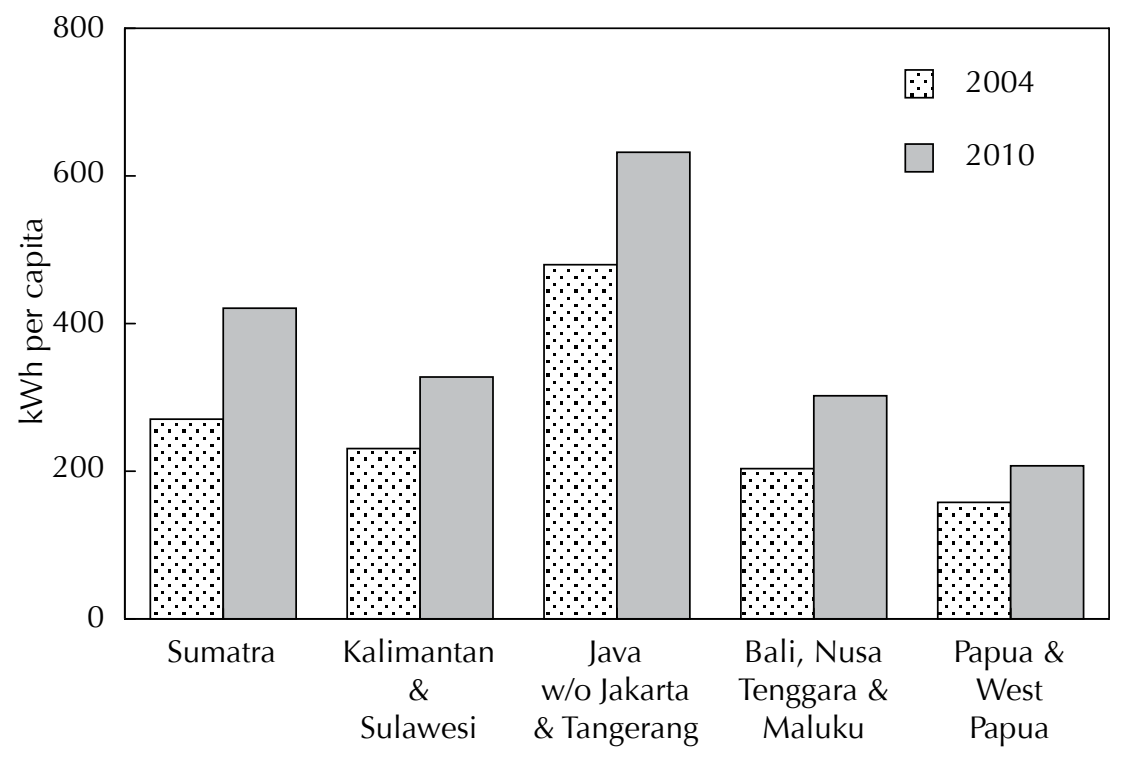

Source: BPS (various years).

\section{Infrastructure}

Although development in Papua has mainly benefited urban areas, most Papuans - including the vast majority of indigenous Papuans - are still dependent on the rural economy. Close to 74 per cent of the population lives in rural areas, with limited access to education and health services, electricity and other economic infrastructure. Improving conditions in rural areas is therefore essential to provide greater equality in education and welfare to Papua-born citizens - surely the main purpose of Papuan development.

One of the chief requirements is to improve rural infrastructure and facilities, with education, energy, trade and transport infrastructure all requiring attention. For example, the poor quality of educational facilities is certainly a factor in the current low levels of educational attainment among Papuans; and deficiencies in energy supply have been a major bottleneck for the development of various sectors, including trade, education and industry.

To provide an indication of the severity of the situation, Figure 18.9 shows electricity consumption per capita in Papua compared with that in the other major island groups. Electricity consumption by Papuan 
households in both 2004 and 2010 was lower than anywhere else in Indonesia; in fact, the per capita consumption of Papua in 2010 was similar to that of Bali and Nusa Tenggara six years earlier, in 2004. The shortage of electricity is especially acute in Papua's rural areas.

Although Papua's low population density and difficult terrain constrain the ability of governments to finance electrification and provide other essential infrastructure in rural areas, solving this problem needs to be a high priority in policy debate and practice.

\subsection{FINAL REMARKS}

In this chapter, we have examined various aspects of development in the two Papuan provinces. In general, using GDP and poverty levels as indicators of development, it appears that the region as a whole has been developing at a faster rate than the national average. Although GDP in the post-2003 province of Papua has been stagnant, economic activities other than mining have grown significantly. We therefore reject the argument that development has been stagnant. On the contrary, we argue that Papua has been one of the most dynamic regions in the country. Nevertheless, both Papuan provinces face serious development challenges.

The main one is to reduce rural poverty, which is still very high - about 41 per cent in 2012, or more than double the national average. Urban poverty, on the other hand, is roughly the same as in the country as a whole. Moreover, annual growth in household income has been much lower in rural than in urban areas, resulting in slower than expected poverty reduction in rural areas.

We have offered several explanations for the failure of rural poverty to decline as quickly as it should have. First, the economies of both provinces are heavily reliant on extractive industries, with the result that fewer government resources are directed to other sectors that could generate broader benefits, such as agriculture. Second, rural areas lack education, health and other infrastructure, resulting in low levels of educational attainment and employment generation. Third, most government spending has been on government administration, at the expense of programs to alleviate rural poverty. The existing poverty alleviation programs are neither adequately funded nor effective. Fourth, there has been a strong urban bias to development. Most of the government budget (including the salaries of government employees) has been spent either in urban areas or in the mining enclaves; these areas are also the beneficiaries of spending by private sector workers employed by extractive and other industries. This has made these areas attractive to migrants, many of whom have set up businesses servicing the surrounding communities. 
This in turn has led to further increases in government budgetary spending in urban areas. Finally, rural population growth has been relatively high, so the benefits of economic growth in rural areas have had to be distributed among a larger population.

In addition to the factors mentioned above, governance and political issues are widely believed to exacerbate rural poverty in Papua. For example, a lack of transparency in the management of public finance has given bureaucrats opportunities to act corruptly. Traditional customary law on land and forest rights is another factor, as it commonly creates conflict between local communities and the government or investors, slowing down development. The process of subdivision of districts into ever-smaller administrative units (pemekaran) has also created conflict between competing elites over the spoils of government, thus inducing uncertainty and delaying the implementation of various poverty alleviation programs (see Nolan, Jones and Solahudin, Chapter 17).

There is also much to be done to improve other welfare indicators, such as public health outcomes. The incidence of tuberculosis, malaria and AIDS, for instance, is much higher in Papua than in other regions. One of the most convincing explanations for the poor health outcomes in Papua is the inadequate government health budgets and the failure to spend funds wisely.

Finally, we have argued that the dependence of both provinces' economies on just a few extractive sectors creates problems. First, the benefits of mining, oil and gas activities have not spread to the general population, particularly in rural areas. Second, the dominance of extractive industries means that there is less incentive to develop other sectors. But as a consequence, when there is a contraction in the extractive industries, the whole economy contracts as well.

Future policies in Papua province and West Papua province should focus on encouraging the development of sectors that would benefit the rural population, such as agriculture and agricultural processing. Larger and better-targeted programs to promote the development of rural infrastructure, education, and trade in goods and services between rural and urban areas should also be established. Finally, to the extent that the rapid growth of the rural population is due to high fertility rates, it may be advisable to re-establish a strong family planning program. 


\section{REFERENCES}

Anggraeni, D. (2007) 'Pattern of commercial and industrial resource use in Papua', in A.J. Marshall and B.M. Beehler (eds) The Ecology of Papua: Part Two, Periplus, Singapore.

Ballard, C. and G. Banks (2009) 'Between a rock and a hard place: corporate strategy at the Freeport mine in Papua, 2001-2006', in B.P. Resosudarmo and F. Jotzo (eds) Working with Nature against Poverty: Development, Resources and the Environment in Eastern Indonesia, Institute of Southeast Asian Studies, Singapore.

BP (2013) 'Tangguh LNG and expansion', available at http:/ / www.bp.com/en/ global/corporate/careers/working-at-bp/our-projects/tangguh.html.

BPS (Badan Pusat Statistik) (various years) Statistik Indonesia [Indonesian Statistics], BPS, Jakarta.

Directorate General for Fiscal Balance (2013) 'Data keuangan daerah setelah TA 2006' [Regional financial data after financial year 2006], Ministry of Finance, Jakarta, available at http://www.djpk.depkeu.go.id/data-series/ data-keuangan-daerah/setelah-ta-2006.

Freeport-McMoRan Copper \& Gold Inc. (2013) Expanding Resources: 2012 Annual Report, Freeport-McMoRan Copper \& Gold Inc., Phoenix.

Freund, A. (2007) 'The HIV/AIDS pandemic in West Papua', Australia West Papua Association, Newcastle.

Garnaut, R. and C. Manning (1972) 'An economic survey of West Irian: Part I', Bulletin of Indonesian Economic Studies, 8(3); 33-65.

Garnaut, R. and C. Manning (1973) 'An economic survey of West Irian: Part II', Bulletin of Indonesian Economic Studies, 9(1); 30-64.

Manning, C. and M. Rumbiak (1989) 'Irian Jaya: economic change, migrants, and indigenous welfare', in H. Hill (ed.) Unity and Diversity: Regional Economic Development in Indonesia since 1970, Oxford University Press, Singapore.

McGibbon, R. (2004) 'Secessionist challenges in Aceh and Papua: is special autonomy the solution?', Policy Studies 10, East-West Center, Washington DC.

McGibbon, R. (2006) Pitfalls of Papua, Lowy Institute for International Policy, Sydney.

National AIDS Commission (2009) 'Republic of Indonesia country report on the follow up to the declaration of commitment on HIV/AIDS (UNGASS): reporting period 2008-2009', National AIDS Commission Republic of Indonesia, Jakarta.

Resosudarmo, B.P., L. Napitupulu, C. Manning and V. Wanggai (2009a) 'Papua I: challenges of economic development in an era of political and economic change', in B.P. Resosudarmo and F. Jotzo (eds) Working with Nature against Poverty: Development, Resources and the Environment in Eastern Indonesia, Institute of Southeast Asian Studies, Singapore.

Resosudarmo, B.P., C. Manning and L. Napitupulu (2009b) ‘Papua II: challenges for public administration and economic policy under special autonomy', in B.P. Resosudarmo and F. Jotzo (eds) Working with Nature against Poverty: Development, Resources and the Environment in Eastern Indonesia, Institute of Southeast Asian Studies, Singapore.

Sedyaningsih, E.R. and S. Gunawan (2009) 'How far is Papua from achieving the goals of Healthy Indonesia 2010?', in B.P. Resosudarmo and F. Jotzo (eds) Working with Nature against Poverty: Development, Resources and the Environment in Eastern Indonesia, Institute of Southeast Asian Studies, Singapore. 
Sumule, A. (ed.) (2003) Mencari Jalan Tengah Otonomi Khusus Provinsi Papua [Finding the Middle Ground on Special Autonomy for Papua], PT Gramedia Pustaka Utama, Jakarta.

Suryadarma, D. and G.W. Jones (2013) Education in Indonesia, Institute of Southeast Asian Studies, Singapore.

TIAP (Tangguh Independent Advisory Panel) (2012) 'Report on operations of the Tanggug LNG project', TIAP, October, available at http:/ / www.bp.com/ content/dam/bp/pdf/sustainability/group-reports/TIAP_Report_2012_ Final1.pdf.

Weisskoff, R. and E. Wolf (1977) 'Linkages and leakages: industrial tracking in an enclave economy', Economic Development and Cultural Change, 25: 607-28.

Widjojo, M.S. (ed.) (2010) Papua Road Map: Negotiating the Past, Improving the Present and Securing the Future, Institute of Southeast Asian Studies, Singapore. 